\title{
A Test for Europe
}

by Herman Van Rompuy

\section{Introduction}

In the recent past, the sovereign debt crisis in the Eurozone has gained in intensity. This is the most serious test that the European Union has faced since long. European leaders from all 27 member states took major decisions, individually and jointly, to bring this storm to rest. We were united by the sheer determination to overcome the Euro crisis. We are aware that there is no quick fix and that the path will be long and arduous. Yet we remain convinced that it is necessary to safeguard the achievements of sixty years of European integration and to lay the foundations for the future.

Over the past year, the European Council welcomed new colleagues, and said goodbye to former ones, after government changes in Ireland, Finland, Portugal, Denmark, Greece, Italy and Belgium. Some of these changes were related to the public debt crisis. Colleagues from two countries agreed to hold parliamentary elections to preserve the financial stability of the Eurozone: in order to help restore market confidence in Spain, and in Slovakia to honour a pledge to contribute to a stronger firewall. These are all signs of how European and national politics are now woven together ever more tightly.

The Lisbon Treaty requires a minimum of four European Council meetings to be held each year. Circumstances have required us to work more closely together. Over the past year, there were five formal European Council meetings, an extraordinary one, one informal meeting of the European Council members, as well as four separate summits of the Heads of State or Government of the Eurozone, which I also chaired.

From the table of the Union's leaders I can testify that, even if we have sometimes frank discussions, there is a strong and fundamental political will to work as equals, to help each other and to move forward as a Union, respecting fully each other's situation. All along our aim has been to establish the right balance between collective solidarity and individual responsibility in safeguarding the 
common European good, be it the single currency, the internal market or a common border. Dealing with the tension between unity and diversity remains the daily bread of our Union.

\section{The Stability of the Eurozone}

Safeguarding the Eurozone's financial stability was again the overriding objective during our more recent meetings. We had a double duty: taking emergency action, such as the setting up and improving of rescue funds, while also putting together, step-by-step, a new economic governance to avoid future problems. Our efforts were a year-long quest for convergence, discipline and integration from 1 January 2011, when we welcomed Estonia as the $17^{\text {th }}$ member of the monetary union, until the end of December, when we defined how to enshrine stricter rules for the Eurozone in a new fiscal stability union.

All colleagues have assumed responsibility for the difficult decisions we have collectively taken. Tough budgetary measures and economic reforms were adopted throughout Europe, in particular in the countries undergoing adjustment programmes - Greece, Ireland and Portugal - and in countries facing market pressure, such as Spain and Italy. Whether defending these austerity measures at home or convincing reluctant parliaments and public opinions to step in with considerable loans for other members states, it required political courage and statesmanship.

The public debt crisis, which began as a further chapter in the global financial and economic crisis of 2008-2009, has hit us hard for two reasons. Firstly, it has brought to the surface structural weaknesses in some European economies, such as unsustainable levels of public or private debt or declining competitiveness. That is why we gave priority to boosting structural growth and jobs. Secondly, the crisis has revealed systemic shortcomings within the Economic and Monetary Union itself. Beyond the immediate actions to safeguard the Eurozone's financial stability, we have therefore focused on restoring the euro's structural credibility. To achieve this aim, raising expectations of a solve-it-all-summit is not helpful. The work will take further time and more meetings in the year ahead.

\section{Stopping Contagion}

Looking back at the year 2011, the major shift seems to have occurred in the course of the summer, with August as the watershed. Indeed, in the first half of the year we worked with a prudent confidence on improving the toolbox we had 
agreed upon in principle at the end of 2010. In the second half of the year however, deteriorating market conditions forced us to re-think our response in view of the crisis' depth.

In a series of meetings in February, March and June, we developed and adopted a comprehensive package of economic measures. This entailed stricter budgetary and macro-economic surveillance, more effective rescue mechanisms, reforms for growth and competitiveness, debt relief and financial sector repair.

By early July, worsening conditions in some of the most exposed economies, in particular in Greece, required us to prove that the Eurozone as such could deal with the risk of financial contagion. From a series of national debt crises the situation was evolving into a systemic concern, threatening the stability of the Eurozone as a whole. I convened a meeting of euro area leaders on 21 July 2011, which proved to be pivotal. We agreed on a second assistance programme for Greece, to be financed by EU member states and the IMF, exceptionally including a voluntary private sector involvement. We also agreed on measures to stop contagion, in particular by making the EFSF rescue fund more effective.

The immediate reaction to the summit's outcome was positive, reassuring markets over the Eurozone's resilience. However, in early August, the crisis intensified, following a misunderstanding and fear that the private sector involvement for Greece might set a precedent for other Euro countries. Some doubts also crept in about the implementation of the package. These proved unfounded in the end: all 17 national parliaments duly approved it within three months - an impressive feat by political standards, even if somewhat slow by market standards. Yet the harm was done. Market volatility began to grow, interest rates for one of the Eurozone's largest economies began to rise dramatically, and this during the very days when brinkmanship in the American Congress about a potential US default fuelled market uncertainty. Moreover, the economic growth was also slowing down sharply worldwide. All these problems fed each other.

In a series of meetings in October, we had to take further decisions on the by now familiar fronts where action was needed: the Greek debt sustainability, the firewall against contagion, the banking sector, economic growth. Moreover, individual member states such as Italy committed to major efforts to consolidate their budgets and improve competitiveness, which helped to restore confidence.

In December, during our last meeting in 2011, we agreed on major steps to bring the Eurozone into safer waters. We further developed and defined our short-term stabilisation tools, for instance providing additional resources to the IMF and 
reviewing our approach to private sector involvement in the ESM treaty, strictly aligning it with IMF principles and practices. In this respect, Greece will remain a unique case. We also had a more fundamental discussion on the systemic response to give to the Euro crisis, resulting in a "fiscal compact". Indeed, in October 2011, the leaders of the Euro area had asked me to prepare a report and roadmap on how to strengthen the economic union. In the long night of 8 to 9 December, colleagues and I gathered to decide the course of action. We quickly agreed on the aim, but as happens in the EU - built after all on treaties, protocols, laws - choosing the legal means proved more delicate. In the end, we decided that in order to improve their budgetary behaviour and economic policy coordination, Eurozone members will sign a separate agreement. All future Euro members indicated their intention to participate in this effort: in itself, this is the best vote of confidence in the future of the single currency.

\section{Discipline and Convergence}

Sound national budgets are essential to safeguard the stability of the monetary union. This is why the Union strengthened its budgetary rules and surveillance mechanisms. The European Council gave a decisive impetus to this work, closely following the legislative work in this field which we had put into motion the year before, and opening a new avenue in order to go further. If we had had all the current tools at our disposal right at the start of the crisis, a lot of harm could have been avoided.

First of all, the basic budgetary rules themselves will be decisively strengthened as a result of the fiscal compact. Eurozone countries commit to balanced budgets, with a maximum structural deficit of 0.5 percent, going beyond current engagements. They will transpose this new fiscal rule into their national legislation before the end of 2012, preferably at constitutional or equivalent level. There is no better constraint than self-constraint.

Furthermore, in order to reinforce compliance with the rules, institutional pressure has been stepped up. Sanctions become quasi-automatic, both correctively and preventively. Participants to the fiscal compact agreed that, in case they breach the deficit rule, a self-defined automatic adjustment will apply. In addition, draft budgetary plans will be examined at an earlier stage by the Commission.

Finally, financial support for countries under an assistance programme is subject to a strict macro-economic conditionality, as is currently the case for Greece, 
Ireland and Portugal. The Commission will take on a stronger role in monitoring the process and in enforcing measures.

Even if sound budgets are a necessary condition to prevent a crisis, some countries have learnt the hard way that they are not sufficient. This is why as of 2012 the Union will closely monitor not only public debt and deficits, as foreseen in the Stability and Growth Pact, but also risks of asset bubbles or trade imbalances. Moreover, all major economic policy reforms which have a potential impact on other members of the euro area will be examined by the Commission.

Countries sharing one currency cannot afford economic divergences as have occurred in the past. Increasing upward convergence was the driving idea behind the so-called "Euro Plus Pact" that we set-up in March. Twenty-three member states took voluntary commitments to work in the same direction in areas such as labour market reforms, pensions and social benefits, or private debts of banks and households. These structural reforms will be instrumental in putting Europe back on the path towards sustainable and job-creating growth.

\section{A Matter of Common Concern}

The crisis has brought about a new way of looking at each other's performance: a stronger sense of common responsibility. In this respect, the reform in economic governance is multifaceted. It is the overall combination of institutional pressure, peer pressure and market pressure which will prevent us from getting into such difficulties again.

The pressure which European political leaders put on each other has become much more intense. Not just because of the new institutional set-up, but also as a result of events. In preserving the stability of the Eurozone as a whole, leaders protect jobs and growth in their own country; those whose countries would have to step in with loans paid for by their tax-payers have strong motives to exercise strong peer surveillance. Phone calls between leaders on the debts of their countries take place on a near daily basis: a very concrete translation of the abstract notion of "interdependence"! The scrutiny of the public and the press has also played a remarkable role in keeping all of us alert.

All in all, we have achieved much in twenty months. With further steps currently under discussion, the Union is giving itself the means to live up to the key principle it enshrined in the Treaties exactly twenty years ago, in Maastricht: "Member States shall regard their economic policies as a matter of common concern". In 2012, we will further examine a deepening of our economic union, a subject 
on which I will report to the March 2012 European Council. In my view it is important to show that we do not only punish those who do not respect the rules but also link our policies. We must demonstrate that the euro is more than a currency: an irreversible project, a common destiny.

\section{A Time to Every Purpose}

In a world of flux and volatility, stable political institutions can bring certainty and continuity and help us shape our destiny. The Union's institutions are quite young - the oldest will turn sixty next year, which is nothing compared to century-old parliaments, councils and courts in many member states. But they share the same aspiration: channelling change, absorbing shocks, setting out new directions.

However, to play this role, institutions need a life and a time of their own. The European Council, a formal institution since the Lisbon Treaty, is no exception. Thanks to the new continuity of my function it is better equipped to steer change, to give orientations or quite practically to follow-up earlier decisions.

Many observers of European politics were struck by the fact that the speed of the markets is not the same as the speed of democracy. Markets indeed have the luxury of moving at the click of a computer mouse. Democratic processes often take long months to achieve a result. This temporal conflict has proved a major challenge. All the more so since, within political time, there are three aspects to be distinguished: the time of parliamentary democracies, determined by legislative procedures, by votes, by the need to get a majority, the time of public opinion, which has to experience a change in reality to be convinced, and the time of implementation, of executing the measures once they are agreed. The latter is vital, especially for structural reforms. In that respect, the request for speedier EU decision-making is sometimes just not credible. It takes time to tie many interests and sensitivities together in a solid decision acceptable to all. When one designs a new house, should it be ready within a week? Time is the politician's cement.

As the institution's first permanent president, I have established from the start good working relations with all other European institutions. The personal trust developed through these quasi-permanent contacts proved essential. This has been the case with European Commission President José Manuel Barroso, with the Eurogroup President Jean-Claude Juncker, with High Representative Catherine Ashton and with Jerzy Buzek, President of the European Parliament. It has 
also been a pleasure to work with the two rotating Council Presidencies of 2011 - first with Hungarian Prime Minister Viktor Orban, and then with Polish Prime Minister Donald Tusk: both bringing élan and a European spirit to the negotiating tables. I also visited practically all members of the European Council in their capitals. In constant dialogue, the 27 Heads of State or Government also seem to meet each other ever more frequently outside Brussels, partly as a consequence of our ongoing work on the Eurozone. Furthermore, the European Council nominated Mario Draghi President of the European Central Bank; he entered office in November and we are confident he will be as reliable a guide as his predecessor Jean-Claude Trichet.

Faced with challenges affecting the material and symbolic heart of the Union, the Euro, all worked in a spirit of cooperation, respect and a sense of shared responsibility. Take the coming-about of the stronger budgetary and macro-economic surveillance and discipline. Following the taskforce which the March 2010 European Council asked me to chair, the Commission made its legislative proposals, which the European Parliament and the Council of ministers discussed intensely (the latter under three Council Presidencies). The final bone of contention between the legislators concerned the "reversed majority vote", which had become the symbol of more automatic decision-making. This obstacle was cleared at the July 2011 euro summit, when all Eurozone leaders recognised the importance of credible compliance. The measures have entered into force on 13 December 2011 and are as of now helping to prevent future turmoil.

In the course of the year, we have also developed the Eurozone's institutional set-up. We decided to have more regular Euro summit meetings, at least twice a year and not only in periods of tensions. These meetings will be chaired by a Euro Summit President, to be elected by Euro area leaders at the same time as the 27 elect the President of the European Council. The existing administrative structures supporting the work of the Euro Finance Ministers have also been strengthened.

Much has been said about the relationship between the members of the Eurozone and the other Member States. My reasoning is simple: it is natural that those who share a common currency - which by the way in the Union is the norm and not the exception - need to take some common decisions. Indeed, problems arose because the interdependence between them was underestimated. However, it is also important to safeguard the integrity of the single market among the 27. This gives the Union cohesion and is the very basis of our prosperity and our role in the world. So we must keep the links between the two types of configurations, 
and any intermediate forms, as close as possible. It will require some creativity now and then, but together much is possible in a spirit of trust.

\section{The Road Ahead}

The world is changing rapidly and so is Europe's place within it. Slow economic and demographic global trends are accelerating, becoming more visible and concrete, confronting us with new challenges.

In facing them, we can draw confidence from the political will we mustered in the past year: a series of major decisions to safeguard our currency and our prosperity, a relentless focus on creating jobs and growth, standing up for our values in the world. We can draw confidence, too, from the courage and resilience which the Europeans have shown in a period where hardship and austerity take their toll: young people urging for change, graduates starting businesses, citizens showing solidarity and a sense of the public good.

In 2012, the European Council will continue to deal with the urgent and the important, acting in a spirit of compromise and responsibility. The stakes are high. The Union's more than 500 million citizens live on the most prosperous and social, the most free and secure continent on earth. The decisions taken by political leaders and by Europeans themselves will determine our future prosperity and indeed the fate of our social and economic model. A civilisation of human dignity, a continent of unity in diversity.

The key for the future is to harness the forces of change. It is the ultimate raison d'être of this institution. In view of the sixty year old history of the Union's unique endeavour - and whichever path we will find or forge - I am confident that, in dealing with the inner tensions and the outer pressure, Europe will continue to reinvent itself, for the better. 